\title{
The cornucopia of intestinal chemosensory transduction
}

\author{
Paul P. Bertrand* \\ Department of Physiology, School of Medical Sciences, University of New South Wales, Sydney, NSW, Australia
}

Edited by:

Gary M. Mawe, University of Vermont,

USA

\section{Reviewed by:}

Michael Schemann, Technische

Universität München, Germany

Simon J. H. Brookes,

Flinders University, Australia

\section{${ }^{*}$ Correspondence:}

Paul P. Bertrand, Department of

Physiology, School of Medical

Sciences, University of New South

Wales, Sydney, NSW 2052, Australia.

e-mail:dr.p.bertrand@gmail.com

\begin{abstract}
The chemosensory transduction mechanisms that the gastrointestinal (GI) tract uses to detect chemical and nutrient stimuli are poorly understood. The Gl tract is presented with a wide variety of stimuli including potentially harmful chemicals or toxins as well as 'normal' stimuli including nutrients, bacteria and mechanical forces. Sensory transduction is at its simplest the conversion of these stimuli into a neural code in afferent nerves. Much of the information encoded is used by the enteric nervous system to generate local reflexes while complementary information is sent to the central nervous system via afferents or by release of hormones to affect behaviour. This review focuses on the chemosensory transduction mechanisms present in the Gl tract. It examines the expression and localisation of the machinery for chemosensory transduction. It summarises the types of cells which might be involved in detecting stimuli and releasing neuroactive transmitters. Finally, it highlights the idea that chemosensory transduction mechanisms in the GI tract utilise many overlapping and complementary mechanisms for detecting and transducing stimuli into reflex action.
\end{abstract}

Keywords: chemosensory, enterochromaffin cell, serotonin, gastrointestinal tract, sensory transduction

\section{INTRODUCTION}

A wide variety of stimuli - chemical, mechanical and others - occur in the gastrointestinal (GI) tract and many of these demand an immediate response. Stimuli include potentially harmful chemicals, toxins and tissue damage as well as 'normal' stimuli which include nutrients, the presence of good bacteria, the mechanical deformation of the epithelium or the stretch of the intestinal wall. In order for the GI tract to respond to these stimuli, a process of sensory transduction must convert the stimuli into information encoded by the activation of neurons. Once transduced, this information is used by the enteric nervous system (ENS) to generate reflexes within the GI tract while other information is sent to the central nervous system via the vagal and dorsal root afferents (Figure 1).

Sensory transduction is at its simplest the conversion of a stimulus into a neural code. The pattern of light on the retina is an example of an external stimulus, while the concentration of proton in the cerebrospinal fluid is an internal stimulus to the chemoreceptors in the medulla. In the GI tract, the mechanisms of sensory transduction seem to be as plentiful as are the potential number of stimuli. Clues as to how the intestinal chemoreceptors may function can be found in the literature on other systems that accomplish similar tasks. For instance, gustatory chemoreceptors are specialised epithelial cells that associate with each other in the taste bud near to the terminals of the sensory nerves. Tastants modulate membrane conductances through G-protein coupled receptors called taste receptors which result in depolarisation of the taste cell and release of transmitters onto the nearby sensory nerve terminals (e.g., Kinnamon and Margolskee, 1996; Herness and Chen, 1997). In the glomus cells of carotid and aortic bodies the chemoreceptors are epithelial cells that contain 5-HT, dopamine or noradrenaline.

Abbreviations: ENS, enteric nervous system; EE cell, enteroendocrine cell; EC cell, enterochromaffin cell; GI, gastrointestinal; serotonin 5-HT, 5-hydroxytryptamine; TRP, transient receptor potential ion channel.
The basis for maintenance of blood oxygenation and $\mathrm{pH}$ by these structures is the modulation of membrane conductances on the glomus cells and release of transmitter onto sensory terminals (Gonzalez et al., 1995).

This review gives an overview of the chemosensory transduction mechanisms present in the GI tract and examines some of theories proposed to account for these mechanisms. The focus will be on more recent data demonstrating taste transduction machinery in the GI tract and on the types of cells which respond to chemical stimuli including the transmitter containing enteroendocrine cells (EE cells). In the end, the idea is put forward that chemosensory transduction mechanisms in the GI tract utilise many overlapping and complementary mechanisms for detecting and transducing stimuli into reflex action. For other recent reviews on chemosensory transduction in the GI tract please see (Dyer et al., 2007; Sternini et al., 2008; Bertrand and Bertrand, 2009; Raybould, 2009). For some of the mechanosensory transduction mechanisms, please see recent papers and reviews (Mazzuoli and Schemann, 2009; Schemann and Mazzuoli, 2009; Smid, 2009; Zagorodnyuk et al., 2009) and for an overview of both chemosensory and mechanosensory mechanisms please see (Grundy, 2005; Blackshaw et al., 2007).

\section{THE MACHINERY OF CHEMOSENSORY TRANSDUCTION CHEMOSENSORY TRANSDUCTION IN THE GI TRACT}

There are several ideas about how the GI tract transduces chemical and nutrient stimuli. One idea is that stimulants cross the epithelium and then interact with specialised receptors on afferent nerve terminals. Some stimulants may be ferried across by transport proteins while other may cross by simple diffusion. Liu et al. (1999) have hypothesised the former mechanism for glucose, suggesting that it is ferried across the epithelium by specific transport proteins (Figure 2A). The latter mechanism is likely to be used by capsaicin which can diffuse through the epithelium where it then has access to TRPV1 receptors (transient receptor potential ion channels) located 


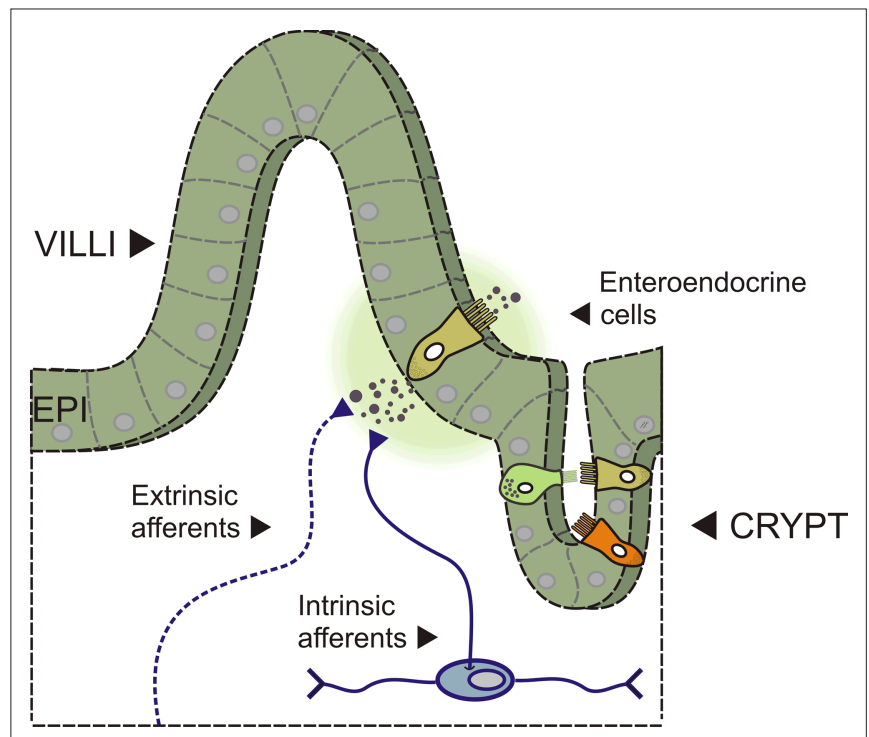

FIGURE 1 | Side view of the intestinal wall showing a villus/crypt unit. A diagram showing a section of intestine with a villus/crypt unit shown in detail. The mucosal epithelium (EPI) contains the enterocytes and the enteroendocrine (EE) cells - specialised epithelial cells that contain neuroactive substances located in secretory granules. Several types of EE cell are depicted (different colours) including the 5-HT containing enterochromaffin (EC) cell (depicted releasing 5-HT near to afferent nerve terminals into the underlying lamina propria). Afferent nerve terminals are from extrinsic sources (vagal and dorsal root ganglia) and from intrinsic sources (myenteric and submucosal afferent/sensory neurons).

on afferent nerve terminals. Alternatively, receptors and transduction machinery may exist on the luminal aspect of specialised epithelial cells within the mucosal epithelium (Figure 2B). The EE cell is one class of epithelial cell which much research has focused on in particular. Many EE cells have luminal microvilli and granules full of a variety of neuroactive transmitters and hormones. It is known that many of these transmitters can act on receptors on the afferent nerve terminals and it is generally believed that this is the sensory transduction mechanism through which many stimulants act.

Work in the last 15 years has focused on the idea that the GI tract uses much of the same transduction machinery as do other senses. Models of how the GI tract senses mechanical or chemical stimuli have been based on hearing transduction (Gershon, 1995), on glucose sensing by the $\beta$-cells of the pancreas (Raybould et al., 2004) and on the internal chemosenses (e.g., carotid bodies). However, what is exciting is the recent evidence that shows that machinery for taste (e.g., Sutherland et al., 2007) and smell (e.g., Braun et al., 2007) are localised to the EE cells in the GI tract. Since these discoveries there has been an explosion of interest in these transduction molecules with studies using selective antibodies and animals with genetic deficiencies to provide evidence for the presence, if not the function, of this transduction machinery in the GI tract. Some of these many new findings are highlighted below.

\section{TASTE MACHINERY IN THE GI TRACT}

Taste is perhaps the best used analogy for explaining GI sensory transduction, even before the discovery of many of the taste molecules in the GI tract (e.g., Rozengurt and Sternini, 2007). It is

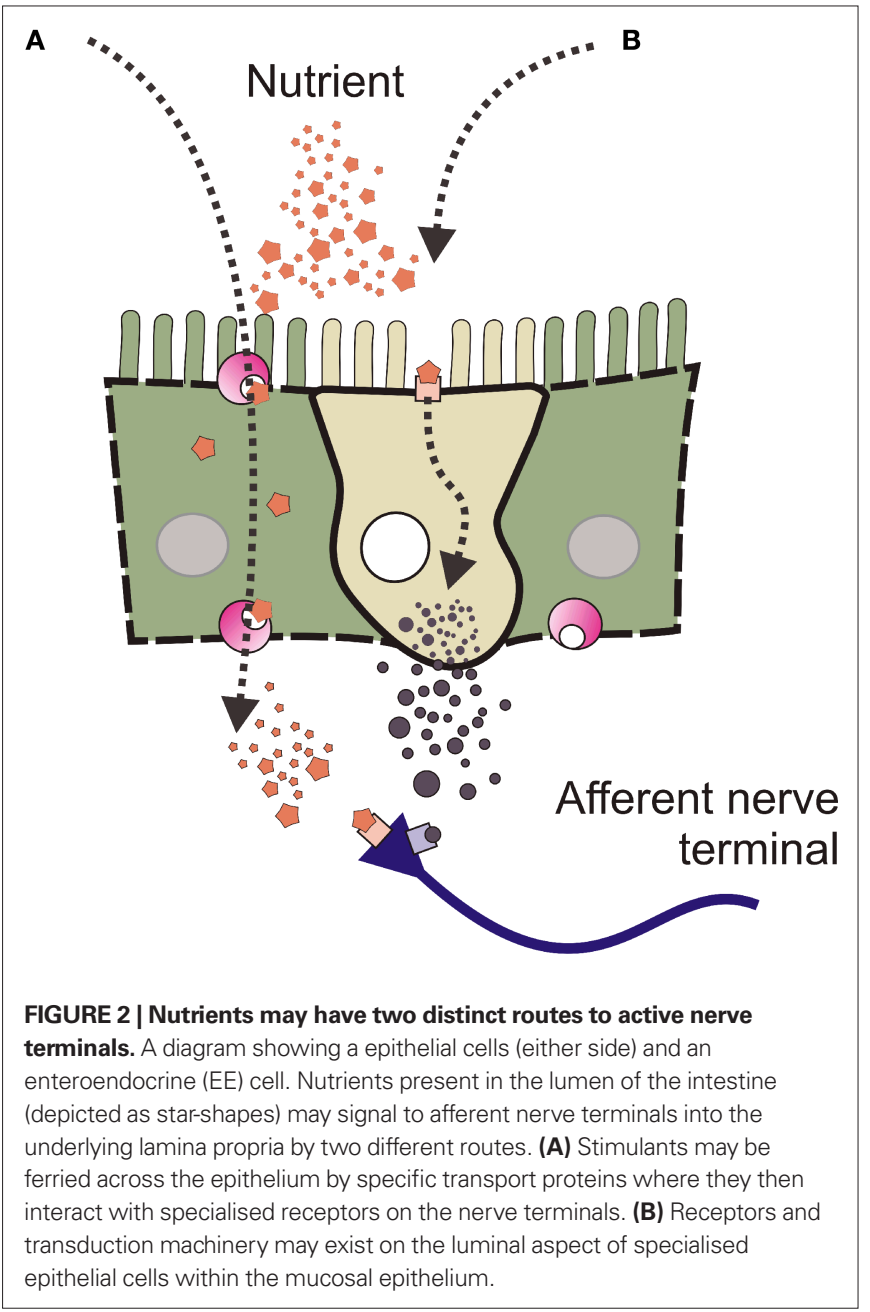

natural to extend lingual taste down into the GI tract. Anatomically, the EE cells and other specialised epithelial cells resemble the taste receptor cells in the taste buds. Both have apical microvilli that are exposed to the ingested contents, and both contain granules with transmitters that can be released. Further, it has been assumed that similar sorts of ingested chemical stimuli would activate both taste receptors and EE cells (e.g., sugars). It is now clear that sub-sets of EE cells have many of the elements that make up the taste transduction machinery (Figure 3). Some of the more important components of the taste transduction machinery are the taste receptors, T1Rs which respond to sweet tastant, and T2Rs which responds to bitter tastants (for review, see Sternini, 2007). These receptors couple to the taste G-protein (gustducin) and to taste specific second messenger systems (phospholipase C; PLC 32 ). There are also specialised ion channel receptors such as TRPM5 which is required for the transduction of bitter, sweet and umami tastes (Liman, 2007).

Concrete interest in components of the taste transduction machinery in the GI tract began in the late 1990's when Hofer et al. $(1996,1998)$ demonstrated $\alpha$-gustducin mRNA and protein in a sub-set of epithelial cells. Interestingly, this first study identified cells that were not EE cells, but a poorly characterised cell called a brush cell (also called a tufted cell). One major issue with accepting that these cells participated in sensory transduction was 


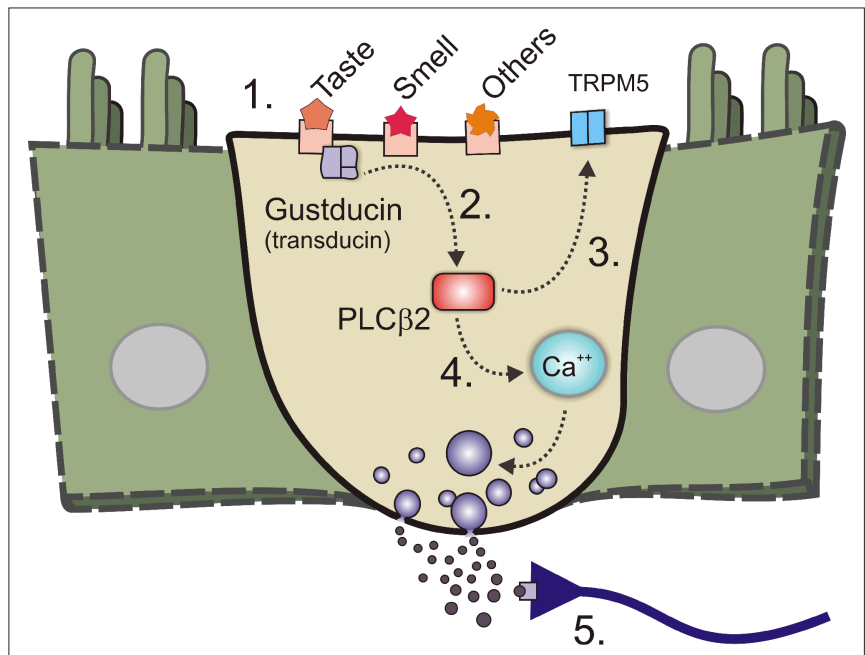

FIGURE 3 | Sensory transduction machinery and the enteroendocrine (EE) cell. A diagram showing an enteroendocrine (EE) cell with machinery. 1. Some of the more important components of the taste transduction machinery are the taste receptors, T1Rs which respond to sweet an umami tastants, andT2Rs which responds to bitter tastants. Receptors for olfactory receptors as well as others exist. 2. These receptors couple to the taste G-protein (gustducin, or in some cases transducin). 3. These in turn couple to taste specific second messenger systems such as phospholipase $\mathrm{C} \beta 2$ (PLCß2). 4. PLCß2 generates second messengers such as diacylglycerol which can activate specialised ion channel receptors like transient receptor potential ion channel M5 (TRPM5) which is required for the transduction of bitter, sweet and umami tastes. 5. Second messengers such as inositol triphosphate are also generated and can release calcium $\left(\mathrm{Ca}^{++}\right)$from intracellular stores and causes transmitter release and nerve terminal activation.

the lack of evidence for granules or other evidence of transmitter storage. Luckily, Hofer et al. had recently shown that nitric oxide synthase was also expressed by the brush cells (Kugler et al., 1994), suggesting at least a plausible sensory transduction pathway via the generation of nitric oxide.

Some of the first work to look beyond gustducin was by Dyer et al. (2005), who showed that T1R sweet taste receptor mRNA and protein (as well as $\alpha$-gustducin) were expressed in the STC-1 enteroendocrine cell line. These data were recently confirmed by studies showing $\alpha$-gustducin in brush cells from mouse stomach (Hass et al., 2007) and in brush cells and some EE cells from mouse small intestine (Sutherland et al., 2007). For example, Sutherland et al. (2007) used immunohistochemical techniques to localise $\alpha$-gustducin and found over half of the cells were brush cells while the remainder were EE cells (of these, 25\% were 5-HT containing enterochromaffin (EC) cells and about 15\% were GLP containing L-cells).

The presence of components of the taste transduction machinery has also been examined in human tissues. When the mucosal epithelium from biopsies were analysed using PCR methods, taste receptors, $\alpha$-gustducin, PLC $\beta 2$ and TRPM5 were found to be expressed along the GI tract (Bezençon et al., 2007). Bezençon et al. also used the promoter for the Trpm 5 gene to express eGFP in a transgenic mouse and then used antibodies to colocalise TRPM5 protein with some morphologically identified EE cells (containing PLC $\beta 2$ and TRPM5) and brush cells (containing TRPM5, $\alpha$-gustducin, T1Rs). Unfortunately, there was no colocalisation of
Trpm5-eGFP expression with EE cell transmitters such as ghrelin, orexin, peptide YY (PYY), glucagon-like peptide (GLP-1), or cholecystokinin (CCK) but recently Kokrashvili et al. (2009) have shown the colocalisation of Trpm5-eGFP with some mouse duodenal EE cells that contain enkephalin and uroguanylin. On the other hand, Jang et al. (2007) in human and mouse demonstrated immunohistochemical localisation of $\alpha$-gustducin in GLP- 1 containing L-cells. Using a cell line, they also showed that sugars caused the release of GLP-1 which was blocked by inhibition of taste receptors or $\alpha$-gustducin (Jang et al., 2007).

The expression levels for components of the taste transduction machinery are not static but seem to respond dynamically to nutrient conditions. For example, Young et al. (2009) have shown in human and mouse that mRNA expression for sweet taste receptors (T1R2 and T1R3 subunits), TRPM5 and $\alpha$-gustducin were inversely related to blood glucose levels. Similarly, the $\mathrm{Na}^{+} /$glucose co-transporter 1 (SGLT-1) has been shown to be upregulated via a taste receptor mediated pathway. Margolskee et al. (2007) have shown that sweet taste receptors (T1R3 subunit) and $\alpha$-gustducin are coupled to the levels of SGLT mRNA expression in mouse small intestine and an endocrine cell line (GLUTag). Similarly, ingested sugars have been found to increase expression of glucose transporter-2 (GLUT2) in rat small intestine with the taste receptors (T1R2 and T1R3 subunits) and $\alpha$-gustducin being implicated in this process (Mace et al., 2009). Finally, molecules involved in the control of fat metabolism have been shown to upregulate T2R bitter receptors on STC-1 cells and in EE cells from mouse intestine (Jeon et al., 2008).

\section{OTHER SENSES IN THE GI TRACT}

Components of the taste transduction machinery are not the only sensory transduction elements which have been localised to the GI tract. Molecules involved in vision and smell transduction have also been found. Hofer et al. (1999) showed that the vision G-protein, transducin, was present in GI epithelium. More recently, Mace et al. $(2007,2009)$ have provided support for this study by showing that transducin could couple through the taste machinery present in rat jejunum. Smell transduction machinery is also present in the GI tract with a recent study by Braun et al. (2007) showing odorants, such as those from roses and raspberries, evoked 5-HT release from an EC cell model (BON cells). In particular, a sub-set of olfactory receptors was detected, a finding supported by Kidd et al. (2008) who showed that activation of class II olfactory receptors stimulated 5-HT release from an EC cell model (KRJ-I cells).

\section{GLUCOSE AND FAT SENSING IN THE GI TRACT}

Glucose sensing has been well reviewed recently; please see Dyer et al. (2007). In brief, sugar sensing has been linked to taste machinery (Mace et al., 2009) and to mechanisms of glucose sensing used by the pancreatic $\beta$-cells (Raybould, 2002; Raybould et al., 2004). Pancreatic $\beta$-cells use the ATP activated potassium channel $\left(\mathrm{K}_{\mathrm{ATP}}\right)$ to monitor glucose concentrations indirectly. In the GI tract glucose evokes enteropancreatic reflexes which are reduced by a $\mathrm{K}_{\mathrm{ATP}}$ blocker (Kirchgessner et al., 1996). The GI tract uses the $\mathrm{Na}^{+}$/glucose cotransporter 1 (SGLT) to transport simple sugars into the enterocyte, and these have also been found on enteric neurons (Liu et al., 1999). Perhaps more importantly, Kidd et al. (2008) have shown mRNA for GLUT1/3 and SGLT1 transporters are enriched in human EC cells 
and have demonstrated release of 5-HT evoked by sugars. Similarly, sweet taste receptors (T1R3 subunit) and $\alpha$-gustducin have been shown to be coupled to SGLT expression in mouse and the GLUTag cell line (Margolskee et al., 2007) and GLUT2 (Mace et al., 2007).

It is clear that lipids affect the motility of the GI tract predominately through the release of CCK from the type of EE cell called the 'I' cell. Fatty acids can induce segmentation in the small intestine (Gwynne et al., 2004) and propulsion in the colon (Grider and Piland, 2007). They can activate enteric sensory neurons (Bertrand et al., 1997) as well as the extrinsic sensory nerves (Eastwood et al., 1998). Fat sensing has been linked to fatty acid receptors which include the short chain fatty acid receptors, FFAR2 (free fatty acid receptor 2; also called GPR43: G-protein coupled receptor 43) and FFAR3 (GPR41) as well as two long chain fatty acid receptors FFAR1 (GPR40) and GPR120 (for reviews see Brown et al., 2005; Ichimura et al., 2009; Wellendorph et al., 2009). FFAR2 and FFAR3 are both known to be expressed within the intestinal mucosa while FFAR1 and FFAR3 have been identified in the cytoplasm of enterocytes and in L-cells but not EC cells (Karaki et al., 2006; Tazoe et al., 2008, 2009). GPR120 has been shown to release CCK from STC-1 cells (Tanaka et al., 2008). There is also evidence that fatty acid transport proteins regulate the uptake of fatty acids (Stahl, 2004) suggesting that they may be capable of regulating the chemosensory transduction of fats.

Many of these actions appear to be via the release of CCK from EE cells, but other mechanisms exist. For example, molecules involved in the control of fat metabolism have been shown to upregulate T2R bitter receptors on STC-1 cells and in EE cells from mouse intestine causing release of CCK and GLP-1 (Jeon et al., 2008). Similarly, short or long chain fatty acids can release 5-HT from the EC cells (Bertrand and Bertrand, 2009) and mice deficient in enzymes that re-synthesize triglyceride may directly regulate the release of GLP-1 and PYY from L-cells (Okawa et al., 2009).

\section{EE CELLS AND THEIR TRANSMITTERS IN GI SENSORY TRANSDUCTION}

The common question in most studies of GI sensory transduction is whether the EE cells contain any of this transduction machinery. EE cells are targeted because they are known to release GI hormones/transmitters and receptor antagonists for these transmitters are known to modulate intestinal reflexes. Let us look more closely at the types EE cells with a particular focus on the 5-HT containing enterochromaffin (EC) cell.

\section{TYPES OF EE CELLS}

The EE cells contain and release secretory granules into the subepithelial space - near where the sensory nerve terminals are. The cells are generated in the crypts and migrate to the tip of the villus; as a result they cannot form lasting appositions with these nerve terminals (Berthoud and Patterson, 1996) so transmission is likely to be paracrine. Most EE cells are of the open type with microvilli accessing the lumen, as has been described above. However, some are of the closed type, having no clear access to lumenal contents. This lack of lumenal contact has been confirmed by serial section (Kusumoto et al., 1988). As these EE cells make contact with the lumen they may have a different role in chemosensory transduction. For instance, EC cells of the closed type may only participate in mechanically evoked responses. Alternatively, closed EE cell types may only respond to release of other mediators, for example, ATP released from epithelial cells (e.g., Cooke et al., 2003).

As Table 1 suggests, a variety of transmitters are found in different types of EE cells. For example, CCK is found only in a type of EE cell called an 'I' cell and is widely believed to participate in signalling the presence of lipids to the extrinsic sensory nerves (e.g., Grundy et al., 1998) and to the intrinsic innervation (e.g., Gwynne et al., 2004). In fact, different types of EE cells contain a host of putative GI hormones $($ transmitters such as neurotensin, somatostatin (SOM) and GABA. Some transmitters are co-stored within a single type of EE cell, while others like 5-HT (EC cells) and CCK (I cells) represent distinct populations of EE cells. Gut hormones such as orexin and ghrelin are also important for nutrient signalling and are contained within G cells and P/D1 cells (also known as X cells), respectively.

A fair question to ask is why there are so many types of EE cell. The simplest explanation is that each type has a specific function and perhaps communicates with a specific sub-population of sensory nerves. There is some evidence for this as mentioned for lipid and CCK containing I cells, and for sugars and GLP containing L-cells. On the other hand, the 5-HT containing EC cells seem to respond to a wide variety of stimulants. It is beyond the scope of this review to examine this issue in detail, but it is likely that different types of EE cell do have a specific function, but that they function together to control GI function. Nonetheless, despite this variety of EE cell types, it is the 5-HT containing EC cell that has received the most experimental attention.

\section{THE EC CELL AND 5-HT}

The EC cells are one of the most studied type of EE cell and for good reason. 5-HT is stored in dense core granules located in the basal and apical parts of the EC cell and EC cells are responsible for

\begin{tabular}{|c|c|c|c|}
\hline Cell type & Function & Granules & $\begin{array}{l}\text { Major transmitters } \\
\text { (minor transmitters) }\end{array}$ \\
\hline \multicolumn{4}{|l|}{ Enteroendocrine } \\
\hline EC cells & Sensory & Yes & $\begin{array}{l}\text { 5-HT (e.g., melatonin, } \\
\text { chromogranin A) }\end{array}$ \\
\hline D cells & Sensory & Yes & Somatostatin \\
\hline CCK (I) cells & Sensory & Yes & Cholecystokinin \\
\hline L cells & Sensory & Yes & $\begin{array}{l}\text { Glucagon-like peptide (GLP) } \\
\text { (peptide YY, oxyntomodulin) }\end{array}$ \\
\hline P/D1 (X) cells & Sensory & Yes & Ghrelin \\
\hline G cells & Sensory & Yes & Gastrin, orexin \\
\hline Mast & Immune & Yes & Histamine $\left(5-\mathrm{HT}^{*}\right)$ \\
\hline Enterocyte & Absorption & No & ATP $^{+}$ \\
\hline Brush (Tufted) & Unknown & No & Nitric oxide synthase \\
\hline Paneth & Enzyme & No & None known \\
\hline Goblet & Mucous & No & None known \\
\hline
\end{tabular}

* Some species like rat and mouse have 5-HT in mast cells. ${ }^{\dagger}$ ATP may be release from enterocytes during mechanical stimuli (Cooke et al., 2003). For a comprehensive review of epithelial EE cell types, see Rindiet al. (2004) with extra information about ghrelin cells (Yabuki et al., 2004), orexin cells (Kirchgessner, 2002) and L-cells (Lim and Brubaker, 2006). 
the production and storage of the largest pool of 5-HT in the body (Erspamer, 1954). Many pharmacology and physiology studies, past and present, suggest that the release of 5-HT from the EC cells is a critical step in the transduction of chemical and mechanical information to the afferent neurons (for reviews see Bertrand, 2003; Grundy, 2006; Bertrand and Bertrand, 2009).

Studies over the past 50 years have shown that the EC cells release 5-HT during physiologically meaningful stimuli (e.g., Bülbring and Crema, 1959; Kirchgessner et al., 1992; Foxx-Orenstein et al., 1996; Grider et al., 1996; Linden et al., 2003; O’Hara et al., 2004). Similarly, nutrients - such as short or long chain fatty acids, peptides, glucose - or chemical stimuli (e.g., acid, base) can release 5-HT from the EC cells (Bertrand and Bertrand, 2009). Once in the lamina propria, high concentrations of released 5-HT are thought to activate sensory nerve terminals via $5-\mathrm{HT}_{3}$ receptors as does exogenously applied 5-HT (Bertrand et al., 2000). Many in vitro studies have shown that $5-\mathrm{HT}_{3}$ receptors are important for initiation or propagation of motor reflexes (Kadowaki et al., 1996; Tuladhar et al., 1997; Grider et al., 1998; Jin et al., 1999) or secretory reflexes (Sidhu and Cooke, 1995; Cooke et al., 1997a,b). Despite this keen interest in the EC cell, studies have yet to firmly nail down the transduction machinery that the EC cell uses to detect luminal stimuli or to couple this to release of 5-HT.

\section{Control of 5-HT release from the EC cell}

Racké, Schwörer and colleagues have described 5-HT overflow from in vitro segments of intestine from a variety of small and large animals (for review, see Racké et al., 1996). 5-HT release was generally reduced when L-type calcium channels were blocked suggesting an external $\mathrm{Ca}^{++}$-dependent process (Forsberg and Miller, 1983). However, upon muscarinic receptor activation release also occurred via calcium from internal stores. Release of 5-HT was also evoked by agonists at other receptors such as adrenoceptors or $5-\mathrm{HT}_{3}$ autoreceptors, while release was inhibited by activation of $\mathrm{GABA}_{\mathrm{A}}$, nicotinic, somatostatin 2 receptors or $5-\mathrm{HT}_{4}$ autoreceptors (Gebauer et al., 1993).

The 5-HT measured using these traditional overflow methods is the sum of many EC cells measured many minutes after release occurs, and far from the site of action; thus, temporal and spatial information are lost. It is not surprising then that other techniques have been used in an attempt to look at the activity of only a few EC cells at a time. Studies of calcium transients in small numbers of EC cells show clearly that apparently identical EC cells respond to transmitter or calcium channel agonist differently (Satoh et al., 1995, 1999; Lomax et al., 1999); although for the most part the pharmacological features found by Racké and Schwörer have been supported.

An attempt to look at single cells has utilised an EC cell model, the BON cell, which is derived from a metastatic human carcinoid tumour of the pancreas (Evers et al., 1994). BON cells have often been used as a model of EC cell function (Christofi et al., 2004; Tran et al., 2004) such as the release of 5-HT by D-glucose application or mechanical stimulation (Kim et al., 2001a,b). Recent studies have looked for a better EC cell model (Siddique et al., 2009) and have instead used a cell line derived from a human carcinoid tumour of the small intestine (KRJ-I) (Kidd et al., 2008) as well as other cell lines (Doihara et al., 2009; Nozawa et al., 2009). There is also the potential for a promising new model of the EC cell from work being done using the 'immortoMouse' (Whitehead and Robinson, 2009).

Studying real single EC cells in vitro has been difficult as they are a relatively small proportion of the epithelial cells, perhaps $1-3 \%$ (Bose et al., 2000; Coates et al., 2004). In addition, there are many other types of EE cells which have similar structural properties. Attempts to aid the study of EC cells have focussed on enriching EC cells populations. One successful approach to enrich the EC cells used techniques developed for the histamine containing enterochromaffin-like cell of the stomach (Oh et al., 2005). Schafermeyer et al. (2004) used sucrose gradients to enrich the EC cell fraction and were able to demonstrate the presence of mRNA for adrenoreceptors, muscarinic and $\mathrm{GABA}_{\mathrm{A}}$ receptors. Recently, Nozawa et al. (2009) used similar enrichment methods to show that TRPA1, the receptor for pungent compounds such as mustard, is expressed by human and rat EC cells. In addition, Kidd et al. (2006, 2008) succeeded in enriching EC cells using fluorescence-activated cell sorting techniques to the point that genechips could be used to show mRNA expression of some taste machinery (Modlin et al., 2006). Finally, Braun et al. (2007) have purified human EC cells by isolating them using laser micro-dissection. Although these enrichment schemes have been successful, they all depend on disrupting the cell-cell connections between EC cells and neighbouring enterocytes, thus, disrupting normal physiological processes.

\section{Detecting 5-HT direct from the EC cell}

A different approach has been used to successful detect 5-HT release from only a few EC cells in vitro, where normal polarity and cell contact is maintained, by using real time electrochemical methods. The chemical structure of 5-HT is such that it is readily oxidized at low voltages; thus, it is particularly well-suited to electrochemical detection methods. When a compound is oxidized, the transfer of electrons can be detected, and quantified. This provides a direct and accurate measure of the number of molecules (i.e., the concentration) at the tip of the electrode. Thus, electrochemical methods allow the accurate measure of the absolute concentrations of 5-HT near the mucosa and, by extension, near the sensory afferent nerve terminals that control GI function and sensation (Keating et al., 2008). We have shown that it is possible to record 5-HT close to the site of release and close to the site of action (Bertrand, 2004; Grundy and Schemann, 2004). Using these methods, 5-HT concentrations near to the mucosa have been shown to be regulated by uptake via the serotonin transporter (Bertrand et al., 2008c) and to be altered during disease state (e.g., Bertrand et al., 2008d,e).

5-HT levels have been measured near the mucosa from a variety of animal models (Bertrand, 2004, 2006b; Bian et al., 2007; Patel et al., 2007; Bertrand et al., 2008a,c), human surgical specimens (Bertrand et al., 2008b) and from BON cells (Braun et al., 2007). Generally carbon fibre electrodes are used, but boron doped diamond coated electrodes have also been used successfully (Bian et al., 2007; Patel et al., 2007). The concentration of 5-HT detected depends on how close the electrode is to the EC cell. The minimal concentrations detected away from the mucosa are less than $100 \mathrm{nM}$ but as the electrode is brought close to, or touching, the mucosal epithelium, 5-HT concentrations rise to over $1 \mu \mathrm{M}$. However, there are several limitations which need to be 
taken into account when touching the epithelial surface as noted by Vanden Berghe (2008). For example, movement of the tissue could cause recordings to be made from different positions or could cause mechanically evoked release. In addition, touching the tissue could damage it mechanically or by the electrical generation of toxic metabolites.

Once released, high concentrations of 5-HT can activate low affinity $5-\mathrm{HT}_{3}$ receptors on sensory afferents (e.g., Hillsley et al., 1998; Bertrand et al., 2000) or act as a paracrine transmitter. Lower concentrations of 5-HT can activate high affinity G-protein coupled receptors such as the 5- $\mathrm{HT}_{7}$ receptor (e.g., Monro et al., 2005) and could potentially act throughout the GI tract (e.g., Tsukamoto et al., 2007) and the ENS. Whether 5-HT can act beyond the GI tract, in the blood as a true hormone, is debatable because under physiological conditions plasma concentrations of 5-HT are kept very low by the actions of the serotonin transporter located on platelets (see Bertrand and Bertrand, 2009). Measuring the absolute levels of 5-HT is important because these levels may substantially alter the activation or desensitization of serotonin receptors on afferent nerve terminals, or on the EC cells themselves. For example, peak concentrations of 5-HT from mouse colon have been measured at approximately $7 \mu \mathrm{M}$, high enough to activate and then desensitise the $5 \mathrm{HT}_{3}$ receptor (Bertrand et al., 2008a,e).

\section{NEW IDEAS IN GI SENSORY TRANSDUCTION MECHANISMS}

The sensory transduction needs of the GI tract are more varied than in many other systems. For example, no other system has to communicate with the central, peripheral and enteric nervous system. A new model of GI sensory transduction should encompass the width and breadth of transmitters, the many specialised cell types and varied transduction machinery present in the GI tract. In fact, there is a 'cornucopia' of sensory transduction mechanisms in the GI tract.

Huizinga and Lammers (2009) have recently made a case for the interconnected and overlapping mechanisms controlling GI function with a focus on pacemakers (interstitial cells of Cajal), intrinsic sensory neurons and 'simple' reflexes like peristalsis. Similarly, Blackshaw et al. (2007) make the point that intrinsic sensory neurons in the ENS are highly interconnected (e.g., Thomas et al., 2000) with many roles and many modulatory events which can change their sensitivity to stimuli. I suggest that these ideas be extended to the transduction of sensory stimuli within the GI tract. Sensory mediators most likely act in concert to produce motor and secretory patterns tuned to the contents and to the region of intestine. One way that this may work is by utilising many overlapping and complementary mechanisms for detecting and transducing stimuli into reflex action. For example, it is unlikely that only one method of glucose sensing operates in the GI tract. There is evidence for direct activation of afferent nerves by sugars (e.g., Liu et al., 1999)

\section{REFERENCES}

Berthoud, H.-R., and Patterson, L. M. (1996). Anatomical relationship between vagal afferent fibers and CCK- immunoreactive enteroendocrine cells in the rat small intestinal mucosa. Acta Anat (Basel) $156,123-131$.
Bertrand, P. P. (2003). ATP and sensory transduction in the enteric nervous system. Neuroscientist 9, 243-260.

Bertrand, P. P. (2004). Real-time detection of serotonin release from enterochromaffin cells of the guinea pig ileum. Neurogastroenterol. Motil. 16, 511-514.

as well as indirect activation via taste receptors on EE cells (e.g., Margolskee et al., 2007) and the involvement of glucose transporters (Mace et al., 2007).

\section{FUTURE DIRECTIONS}

We are well on the way to understanding the role of 5-HT containing EC cells thanks to work which has lead to their enrichment and a subsequent global survey of EC cell genes (e.g., Kidd et al., 2006). The selective real time recording of 5-HT during reflexes (e.g., Bertrand, 2006a) is also helping with this understanding. Other EE cell types are not as well characterised but new work to generate transgenic mice with specific expression of a fluorescent protein in GLP containing L-cells (Reimann et al., 2008), CCK containing I cells (Samuel et al., 2008) and TRPM5 expressing EE cells (Bezençon et al., 2007) will undoubtedly help. Another hot topic will be to define the control of EE cell proliferation as has been done for the EC cells (e.g., O'Hara and Sharkey, 2007; Yadav et al., 2008). Finally, the physiological functions in the GI tract of these neuroactive transmitters after they are released, especially when released together, has not yet been defined.

Control of the GI tract is at once complex yet simple as there are many stimuli, but few outcomes. The challenge is to determine how these many signals act in concert to produce coordinated activity. There is also a need to re-examine stimulants that cause EE cells to release transmitters. Genetic clues have provided potential stimulants to be tested while the enrichment of some sub-types of EE cells has provided a standard upon which to test. Perhaps a more important goal will be to translate these insights into useful information about the physiology or pathophysiology of the EE cell. In the end, there are many types of EE cell, each with an important role in paracrine signalling which function together, rather than alone.

\section{CONCLUSIONS}

The GI tract senses the luminal contents and signals to the extrinsic and intrinsic nerves in the wall of the gut to produce motor and secretory patterns tuned to the contents and to the region of intestine. The EE cells play a key role in helping to transduce these signals by converting chemical, nutrient or mechanical stimuli into the release of neuroactive transmitters. Proteins once thought specific for taste or other sensory transduction systems have been implicated in controlling release of these neuroactive transmitters from EE cells. It is time to embrace the idea that many overlapping and complementary mechanisms of sensory transduction are present in the GI tract.

\section{ACKNOWLEDGMENTS}

Kind thanks to Dr Rebecca Bertrand for reading this manuscript and for providing helpful comments. Financial support from the School of Medical Sciences UNSW and NH\&MRC (Australia) project grants \# 510202, 566642.

Bertrand, P. P. (2006a). Real-time measurement of serotonin release and motility in guinea pig ileum. J. Physiol. 577, 689-704.

Bertrand, P. P. (2006b). Real-time release of serotonin from mouse ileum. Gastroenterology 130(Suppl. 2), A256.
Bertrand, P. P., Barajas, A., Bertrand, R. L., and Lomax, A. E. (2008a). Inflammation-induced increases in the release and uptake of serotonin in mouse colon. Fundam. Clin. Pharmacol. 22(Suppl. 2), 121.

Bertrand, P. P., Bertrand, R. L., and Liu, L. (2008b).Characterisation of serotonin 
release from human colonic mucosa using real-time electrochemistry. Neurogastroenterol. Motil. 20(Suppl. 1), 43.

Bertrand, P. P., Hu, X., Mach, J., and Bertrand, R. L. (2008c). Serotonin (5HT) release and uptake measured by real-time electrochemical techniques in the rat ileum. Am. J. Physiol. 295, G1228-G1236.

Bertrand, P. P., Senadheera, S., Markus, I., Bertrand, R. L., Liu, L., Morris, M. J. (2008d). Intestinal serotonin signalling measured in high-fat diet rats using electrochemical techniques. Neurogastroenterol. Motil. 20(Suppl. 1), 23.

Bertrand, R. L., Barajas-Espinosa, A., Nesbit, S., Bertrand, P. P., and Lomax, A. E. (2008e). Enhanced serotonin release and uptake in DSS-treated mouse colon. Neurogastroenterol. Motil. 20(Suppl. 1) 63.

Bertrand, P. P., and Bertrand, R. L. (2009). Serotonin release and uptake in the gastrointestinal tract. Auton. Neurosci. doi:10.1016/j.autneu.2009.08.002.

Bertrand, P. P., Kunze, W. A., Bornstein, J. C., Furness, J. B., and Smith, M. L. (1997). Analysis of the responses of myenteric neurons in the small intestine to chemical stimulation of the mucosa. Am. J. Physiol. 273, G422-435.

Bertrand, P. P., Kunze, W. A., Furness, J. B., and Bornstein, J. C. (2000). The terminals of myenteric intrinsic primary afferent neurons of the guinea-pigileum are excited by 5 -hydroxytryptamine acting at 5-hydroxytryptamine-3 receptors. Neuroscience 101, 459-469.

Bezençon, C., le Coutre, J., and Damak, S. (2007). Taste-signaling proteins are coexpressed in solitary intestinal epithelial cells. Chem. Senses 32, 41-49.

Bian, X., Patel, B., Dai, X., Galligan, J. J., and Swain, G. (2007). High mucosal serotonin availability in neonatal guinea pig ileum is associated with low serotonin transporter expression. Gastroenterology 132, 2438-2447.

Blackshaw, L. A., Brookes, S. J., Grundy, D., and Schemann, M. (2007). Sensory transmission in the gastrointestinal tract. Neurogastroenterol. Motil. 19, 1-19.

Bose, M., Nickols, C., Feakins, R., and Farthing, M. J. (2000). 5-hydroxytryptamine and enterochromaffin cells in the irritable bowel syndrome. Gastroenterology, 118, A563.

Braun, T., Voland, P., Kunz,L., Prinz, C., and Gratzl, M. (2007). Enterochromaffin cells of the human gut: sensors for spices and odorants. Gastroenterology 132, 1890-1901.

Brown, A. J., Jupe, S., and Briscoe, C. P. (2005). A family of fatty acid binding receptors. DNA Cell Biol. 24, 54-61.
Bülbring, E., and Crema, A. (1959). The release of 5-hydroxytryptamine in relation to pressure exerted on the intestinal mucosa. J. Physiol. 146, 18-28.

Christofi, F. L., Kim, M., Wunderlich, J. E., Xue, J., Suntres, Z., Cardounel, A., Javed, N. H., Yu, J. G., Grants, I., and Cooke, H. J. (2004). Endogenous adenosine differentially modulates 5-hydroxytryptamine release from a human enterochromaffin cell model. Gastroenterology 127, 188-202.

Coates, M. D., Mahoney, C. R., Linden, D. R., Sampson, J. E., Chen, J., Blaszyk, H., Crowell, M. D., Sharkey, K. A., Gershon, M. D., Mawe, G. M., and Moses, P. L. (2004). Molecular defects in mucosal serotonin content and decreased serotonin reuptake transporter in ulcerative colitis and irritable bowel syndrome. Gastroenterology 126, 1657-1664.

Cooke, H. J., Sidhu, M., and Wang, Y.-Z. (1997a).5-HT activates neural reflexes regulating secretion in the guinea-pig colon. Neurogastroenterol. Motil.9, 181-186.

Cooke, H. J., Sidhu, M., and Wang, Y.Z. (1997b). Activation of 5-HT1P receptors on submucosal afferents subsequently triggers VIP neurons and chloride secretion in the guineapig colon. J. Auton. Nerv. Syst. 66, 105-110.

Cooke, H. J., Wunderlich, J., and Christofi, F. L. (2003). "The force be with you": ATP in gut mechanosensory transduction. News Physiol. Sci. $18,43-49$.

Doihara, H., Nozawa, K., Kojima, R., Kawabata-Shoda, E., Yokoyama, T., and Ito, H. (2009). QGP-1 cells release 5-HT via TRPAl activation; a model of human enterochromaffin cells. Mol Cell Biochem 331, 239-245.

Dyer, J., Daly, K., Salmon, K. S., Arora, D. K., Kokrashvili, Z., Margolskee, R. F., and Shirazi-Beechey, S. P. (2007). Intestinal glucose sensing and regulation of intestinal glucose absorption. Biochem. Soc. Trans. 35, 1191-1194.

Dyer, J., Salmon, K. S., Zibrik, L., and Shirazi-Beechey, S. P. (2005). Expression of sweet taste receptors of the T1R family in the intestinal tract and enteroendocrine cells. Biochem. Soc. Trans. 33, 302-305.

Eastwood, C., Maubach, K., Kirkup, A. J., and Grundy, D. (1998). The role of endogenous cholecystokinin in the sensory transduction of luminal nutrient signals in the rat jejunum. Neurosci. Lett. 254, 145-148.

Erspamer, V. (1954). The pharmacology of indolealkylamines. Pharmacol. Rev. 6, 425-487.

Evers, B. M., Ishizuka, J., Townsend, C. M. Jr., and Thompson, J. C. (1994).
The human carcinoid cell line, BON. A model system for the study of carcinoid tumors. Ann. N. Y. Acad. Sci. 733, 393-406.

Forsberg, E. J., and Miller, R. J. (1983). Regulation of serotonin release from rabbit intestinal enterochromaffin cells. J. Pharmacol. Exp. Ther. 227, 755-766.

Foxx-Orenstein, A. E., Kuemmerle, J. F., and Grider, J. R. (1996). Distinct 5HT receptors mediate the peristaltic reflex induced by mucosal stimuli in human and guinea pig intestine. Gastroenterology 111, 1281-1290.

Gebauer, A., Merger, M., and Kilbinger, H. (1993). Modulation by 5-HT3 and 5-HT4 receptors of the release of 5-hydroxytryptamine from the guinea-pig small intestine. Naunyn. Schmiedebergs Arch. Pharmacol. 347 137-140.

Gershon, M. D. (1995). Localization and neurochemical aspects of serotonin in the gut. In Serotonin and Gastrointestinal Function, T. S. Gaginella and J. J. Galligan, eds (Boca Raton, CRC Press), pp. 11-32.

Gonzalez, C., Lopez-Lopez, J. R., Obeso, A., Perez-Garcia, M. T., and Rocher, A. (1995). Cellular mechanisms of oxygen chemoreception in the carotid body. Respir. Physiol. 102, 137-147.

Grider, J. R., Foxx-Orenstein, A. E., and Jin, J.G. (1998). 5-hydroxytryptamine receptor agonists initiate the peristaltic reflex in human, rat, and guinea pig intestine. Gastroenterology 115, 370-380.

Grider, J. R., Kuemmerle, J. F., and Jin, J. G. (1996). 5-HT released by mucosal stimuli initiates peristalsis by activating 5-HT4/5-HT1p receptors on sensory CGRP neurons. Am. J. Physiol. 270, G778-G782.

Grider, J. R., and Piland, B. E. (2007) The peristaltic reflex induced by short-chain fatty acids is mediated by sequential release of $5-\mathrm{HT}$ and neuronal CGRP but not BDNF. Am. J. Physiol. Gastrointest. Liver Physiol. 292, G429-G437.

Grundy, D. (2005). Sensory signals from the gastrointestinal tract. J. Pediatr. Gastroenterol. Nutr. 41(Suppl. 1), S7-S9.

Grundy, D. (2006). Serotonin and sensory signalling from the gastrointestinal lumen. J. Physiol. 575, 1-2.

Grundy, D., Hillsley, K., Kirkup, A. J., and Richards, W. (1998). Mesenteric afferent sensitivity to cholecystokinin and 5-hydroxytryptamine. DTW. Dtsch. Tierarztl. Wochenschr. 105, 466-468.

Grundy, D., and Schemann, M. (2004). Serotonin in the gut: pretty when it gets down to the nitty gritty. Neurogastroenterol. Motil. 16 507-509.
Gwynne, R. M., Thomas, E.A., Goh, S.M., Sjovall, H., and Bornstein, J. C. (2004). Segmentation induced by intraluminal fatty acid in isolated guinea-pig duodenum and jejunum. J. Physiol. 556, 557-569.

Hass, N., Schwarzenbacher, K., and Breer, H. (2007). A cluster of gustducin-expressing cells in the mouse stomach associated with two distinct populations of enteroendocrine cells. Histochem. Cell Biol. 128, 457-471.

Herness, S., and Chen, Y. (1997). Serotonin inhibits calcium-activated $\mathrm{K}^{+}$current in rat taste receptor cells. Neuroreport 8, 3257-3261.

Hillsley, K., Kirkup, A. J., and Grundy, D. (1998). Direct and indirect actions of 5-hydroxytryptamine on the discharge of mesenteric afferent fibres innervating the rat jejunum. J. Physiol. 506, 551-561.

Hofer, D., Asan, E., and Drenckhahn, D. (1999). Chemosensory perception in the gut. News Physiol. Sci. 14, 18-23.

Hofer, D., Jons, T., Kraemer, J., and Drenckhahn,D. (1998). From cytoskeleton to polarity and chemoreception in the gut epithelium. Ann. N. Y. Acad. Sci. 859, 75-84, 75-84.

Hofer, D., Puschel, B., and Drenckhahn, D. (1996). Taste receptor-like cells in the rat gut identified by expression of alpha-gustducin. Proc. Natl. Acad. Sci. U.S.A. 93, 6631-6634.

Huizinga, J. D., and Lammers, W. J. (2009). Gut peristalsis is governed by a multitude of cooperating mechanisms. Am. J. Physiol. Gastrointest. Liver Physiol. 296:G1-G8.

Ichimura, A., Hirasawa, A., Hara, T., and Tsujimoto, G. (2009). Free fatty acid receptors act as nutrient sensors to regulate energy homeostasis. Prostaglandins Other Lipid Mediat. 89, 82-88.

Jang, H. J., Kokrashvili, Z., Theodorakis, M. J., Carlson, O. D., Kim, B. J., Zhou, J., Kim, H. H., Xu, X., Chan, S. L., Juhaszova, M., Bernier, M., Mosinger, B., Margolskee, R. F., and Egan, J. M. (2007). Gut-expressed gustducin and taste receptors regulate secretion of glucagon-like peptide-1. Proc. Natl. Acad. Sci. U.S.A. 104, 15069-15074.

Jeon, T. I., Zhu, B., Larson, J. L., and Osborne, T. F. (2008). SREBP-2 regulates gut peptide secretion through intestinal bitter taste receptor signaling in mice. J. Clin. Invest. 118, 3693-3700.

Jin, J. G., Foxx-Orenstein,A. E., and Grider, J. R. (1999). Propulsion in guinea pig colon induced by 5-hydroxytryptamine (HT) via 5-HT4 and 5-HT3 receptors. J. Pharmacol. Exp. Ther. 288, 93-97.

Kadowaki, M., Wade, P. R., and Gershon, M. D. (1996). Participation of 5-HT3, 
5-HT4, and nicotinic receptors in the peristaltic reflex of guinea pig distal colon. Am. J. Physiol. 271, G849-G857.

Karaki, S., Mitsui, R., Hayashi, H., Kato, I., Sugiya, H., Iwanaga, T., Furness, J. B., and Kuwahara, A. (2006). Short-chain fatty acid receptor, GPR43, is expressed by enteroendocrine cells and mucosal mast cells in rat intestine. Cell Tissue Res. 324, 353-360.

Keating, C., Beyak, M., Foley, S., Singh, G., Marsden, C., Spiller, R., and Grundy, D. (2008). Afferent hypersensitivity in a mouse model of post-inflammatory gut dysfunction: role of altered serotonin metabolism. J. Physiol. 586, 4517-4530.

Kidd, M., Modlin, I. M., Eick, G. N., and Champaneria, M.C. (2006). Isolation, functional characterization, and transcriptome of Mastomys ileal enterochromaffin cells. Am. J. Physiol. 291, G778-G791.

Kidd, M., Modlin, I. M., Gustafsson, B. I., Drozdov, I., Hauso, O., and Pfragner, R. (2008).Luminal regulation of normal and neoplastic human EC cell serotonin release is mediated by bile salts, amines, tastants, and olfactants. Am. J. Physiol. Gastrointest. Liver Physiol. 295, G260-G272.

Kim, M., Cooke, H. J., Javed, N. H., Carey, H. V., Christofi, F., and Raybould, H. E. (2001a). D-glucose releases 5-hydroxytryptamine from human BON cells as a model of enterochromaffin cells. Gastroenterology 121, 1400-1406.

Kim, M., Javed, N. H., Yu, J. G., Christofi, F., and Cooke, H. J. (2001b). Mechanical stimulation activates Galphaq signaling pathways and 5-hydroxytryptamine release from human carcinoid BON cells. J. Clin. Invest. 108, 1051-1059.

Kinnamon, S. C., and Margolskee, R. F. (1996). Mechanisms of taste transduction. Curr. Opin. Neurobiol. 6, 506-513.

Kirchgessner, A. L. (2002). Orexins in the brain-gut axis. Endocr. Rev. 23, 1-15.

Kirchgessner,A.L.,Liu,M.-T, and Gershon, M. D. (1996). In situ identification and visualization of neurons that mediate enteric and enteropancreatic reflexes. J. Comp. Neurol. 371, 270-286.

Kirchgessner, A. L., Tamir, H., and Gershon, M. D. (1992). Identification and stimulation by serotonin of intrinsic sensory neurons of the submucosal plexus of the guinea pig gut: activityinduced expression of Fos immunoreactivity. J. Neurosci. 12, 235-248.

Kokrashvili,Z., Rodriguez, D., Yevshayeva, V., Zhou, H., Margolskee, R. F., and Mosinger, B. (2009). Release of endogenous opioids from duodenal enteroendocrine cells requires Trpm5. Gastroenterology 137, 598-606, 606, e591-e592.
Kugler, P., Hofer, D., Mayer, B., and Drenckhahn, D. (1994). Nitric oxide synthase and NADP-linked glucose6-phosphate dehydrogenase are colocalized in brush cells of rat stomach and pancreas. J. Histochem. Cytochem. 42, 1317-1321.

Kusumoto, Y., Grube, D., Sato, A. G., Kaneda, K., and Nakamae, E. (1988). Cytology and arrangement of enterochromaffin (EC) cells in the human stomach. Arch. Histol. Cytol. 51, 271-276.

Lim, G. E., and Brubaker, P. L. (2006). Glucagon-like peptide 1 secretion by the L-cell: the view from within. Diabetes 55, S70-S77.

Liman, E. R. (2007). TRPM5 and taste transduction. Handb Exp Pharmacol 287-298.

Linden, D. R., Chen, J. X., Gershon, M. D., Sharkey, K. A., and Mawe, G. M. (2003). Serotonin availability is increased in mucosa of guinea pigs with TNBS-induced colitis. Am. J. Physiol. Gastrointest. Liver Physiol. 285, G207-G216.

Liu, M., Seino, S., and Kirchgessner, A. L. (1999). Identification and characterization of glucoresponsive neurons in the enteric nervous system. J. Neurosci. 19, 10305-10317.

Lomax, R. B., Gallego, S., Novalbos, J., Garcia, A. G., and Warhurst, G. (1999). L-Type calcium channels in enterochromaffin cells from guinea pig and human duodenal crypts: an in situ study. Gastroenterology 117, 1363-1369.

Mace, O. J., Affleck, J., Patel, N., and Kellett, G. L. (2007). Sweet taste receptors in rat small intestine stimulate glucose absorption through apical GLUT2. J. Physiol. 582, 379-392.

Mace, O. J., Lister, N., Morgan, E., Shepherd, E., Affleck, J., Helliwell, P., Bronk, J. R., Kellett, G. L., Meredith, D., Boyd, R., Pieri, M., Bailey, P. D., Pettcrew, R., and Foley, D. (2009). An energy supply network of nutrient absorption coordinated by calcium and T1R taste receptors in rat small intestine. J. Physiol. 587, 195-210.

Margolskee, R. F., Dyer, J., Kokrashvili, Z., Salmon, K. S., Ilegems, E., Daly, K., Maillet, E. L., Ninomiya, Y., Mosinger, B., and Shirazi-Beechey, S. P. (2007). T1R3 and gustducin in gut sense sugars to regulate expression of $\mathrm{Na}+$-glucose cotransporter 1. Proc. Natl. Acad. Sci. U.S.A. 104, 15075-15080.

Mazzuoli, G., and Schemann, M. (2009). Multifunctional rapidly adapting mechanosensitive enteric neurons (RAMEN) in the myenteric plexus of the guinea pig ileum. J. Physiol. 587, 4681-4694.

Modlin, I. M., Kidd, M., Pfragner, R., Eick, G.N., and Champaneria, M.C.(2006).
The functional characterization of normal and neoplastic human enterochromaffin cells. J. Clin. Endocrinol. Metab. 91, 2340-2348.

Monro, R.L., Bornstein, J.C., and Bertrand, P. P. (2005). Slow excitatory postsynaptic potentials in myenteric $\mathrm{AH}$ neurons of the guinea-pig ileum are reduced by the 5-hydroxytrytamine7 receptor antagonist SB 269970. Neuroscience 134, 975-986.

Nozawa, K., Kawabata-Shoda, E., Doihara, H., Kojima, R., Okada, H., Mochizuki, S., Sano, Y., Inamura, K., Matsushime, H., Koizumi, T., Yokoyama, T., and Ito, H. (2009). TRPAl regulates gastrointestinal motility through serotonin release from enterochromaffin cells. Proc. Natl. Acad. Sci. U.S.A. 106, 3408-3413.

O'Hara, J. R., Ho, W., Linden, D. R., Mawe, G. M., and Sharkey, K. A. (2004) Enteroendocrine cells and 5-HT availability are altered in mucosa of guinea pigs with TNBS ileitis. Am. J. Physiol. Gastrointest. Liver Physiol.287, G998-G1007.

O'Hara, J. R., and Sharkey, K. A. (2007) Proliferative capacity of enterochromaffin cells in guinea-pigs with experimental ileitis. Cell Tissue Res. 329, 433-441.

Oh, D. S., Lieu, S. N., Yamaguchi, D. J. Tachiki, K., Lambrecht, N., Ohning, G. V., Sachs, G., Germano, P. M., and Pisegna, J. R. (2005). PACAP regulation of secretion and proliferation of pure populations of gastric ECL cells. J. Mol. Neurosci. 26, 85-97.

Okawa,M.,Fujii,K.,Ohbuchi,K.,Okumoto, M.,Aragane, K., Sato, H., Tamai, Y., Seo T., Itoh, Y., and Yoshimoto, R. (2009). Role of MGAT2 and DGAT1 in the release of gut peptides after triglyceride ingestion. Biochem. Biophys. Res. Commun. 390, 377-381.

Patel, B. A., Bian, X., Quaiserova-Mocko, V., Galligan, J. J., and Swain, G. M (2007). In vitro continuous amperometric monitoring of 5-hydroxytryptamine release from enterochromaffin cells of the guinea pig ileum. Analyst 132, 41-47.

Racké, K., Reimann, A., Schwörer, H., and Kilbinger, H. (1996). Regulation of 5HT release from enterochromaffin cells. Behav. Brain Res. 73, 83-87.

Raybould,H.E. (2002).Visceral perception: sensory transduction in visceral afferents and nutrients. Gut 51, i11-i14.

Raybould,H.E.(2009). Gutchemosensing interactionsbetweengutendocrinecells and visceral afferents. Auton. Neurosci. doi:10.1016/j.autneu.2009.07.007.

Raybould, H. E., Cooke, H. J., and Christofi, F. L. (2004). Sensory mechanisms: transmitters, modulators and reflexes. Neurogastroenterol. Motil. 16(Suppl. 1), 60-63.
Reimann, F., Habib, A. M., Tolhurst, G., Parker, H. E., Rogers, G. J., and Gribble, F. M. (2008). Glucose sensing in L cells: a primary cell study. Cell Metab. 8, 532-539.

Rindi, G., Leiter, A. B., Kopin, A. S., Bordi, C., and Solcia, E. (2004). The "normal" endocrine cell of the gut: changing concepts and new evidences. Ann. N. Y. Acad. Sci. 1014, 1-12.

Rozengurt, E., and Sternini, C. (2007). Taste receptor signaling in the mammalian gut. Curr. Opin. Pharmacol. 7, 557-562.

Samuel, B. S., Shaito, A., Motoike, T., Rey, F. E., Backhed, F., Manchester, J. K., Hammer, R. E., Williams, S. C., Crowley, J., Yanagisawa, M., and Gordon, J. I. (2008). Effects of the gut microbiota on host adiposity are modulated by the short-chain fattyacidbinding $\mathrm{G}$ protein-coupled receptor, Gpr41. Proc. Natl. Acad. Sci. U.S.A. 105, 16767-16772.

Satoh, Y., Habara, Y., Ono, K., and Kanno, T. (1995). Carbamylcholine- and catecholamine-induced intracellular calcium dynamics of epithelial cells in mouse ileal crypts. Gastroenterology 108, 1345-1356.

Satoh, Y., Williams, M. R., and Habara, Y. (1999). Effects of AIF4- and ATP on intracellular calcium dynamics of crypt epithelial cells in mouse small intestine. Cell Tissue Res. 298, 295-305.

Schafermeyer, A., Gratzl, M., Rad, R., Dossumbekova, A., Sachs, G., and Prinz, C. (2004). Isolation and receptor profiling of ileal enterochromaffin cells. Acta Physiol. Scand. 182, 53-62.

Schemann, M., and Mazzuoli, G. (2009). Multifunctional mechanosensitive neurons in the enteric nervous system. Auton Neurosci. doi: 10.1016/j.autneu.2009.08.003.

Siddique, Z. L., Drozdov, I., Floch, J., Gustafsson, B. I., Stunes, K., Pfragner, R., Kidd, M., and Modlin, I. M. (2009). KRJ-I and BON cell lines: defining an appropriate enterochromaffin cell neuroendocrine tumor model. Neuroendocrinology 89, 458-470.

Sidhu, M., and Cooke, H. J. (1995). Role for 5-HT and ACh in submucosal reflexes mediating colonic secretion. Am. J. Physiol. 269, G346-G351.

Smid, S. D. (2009). Neuronal mechanosensitivity in the gastrointestinal tract. In Mechanosensitivity of the Nervous System, Vol. 2, A. Kamkim and I. Kiseleva, eds (Dordrecht, Springer), pp. 87-103.

Stahl, A. (2004). A current review of fatty acid transport proteins (SLC27). Pflugers Arch. 447, 722-727.

Sternini, C. (2007). Taste receptors in the gastrointestinal tract. IV. Functional 
implications of bitter taste receptors in gastrointestinal chemosensing. Am. J. Physiol. Gastrointest.Liver Physiol.292, G457-G461.

Sternini, C., Anselmi, L., and Rozengurt, E. (2008). Enteroendocrine cells: a site of 'taste' in gastrointestinal chemosensing. Curr. Opin. Endocrinol. Diabetes Obes. 15, 73-78.

Sutherland, K., Young, R. L., Cooper, N. J., Horowitz, M., and Blackshaw, L. A. (2007). Phenotypic characterization of taste cells of the mouse small intestine. Am. J. Physiol. Gastrointest. Liver Physiol. 292, G1420-G1428.

Tanaka, T., Katsuma, S., Adachi, T., Koshimizu, T. A., Hirasawa, A., and Tsujimoto, G. (2008). Free fatty acids induce cholecystokinin secretion through GPR120. Naunyn Schmiedebergs Arch. Pharmacol. 377, 523-527.

Tazoe, H., Otomo, Y., Kaji, I., Tanaka, R., Karaki, S. I., and Kuwahara, A. (2008). Roles of short-chain fatty acids receptors, GPR41 and GPR43 on colonic functions. J. Physiol. Pharmacol. 59(Suppl. 2), 251-262.

Tazoe, H., Otomo, Y., Karaki, S., Kato, I., Fukami, Y., Terasaki, M., and Kuwahara, A. (2009). Expression of short-chain fatty acid receptor GPR41 in the human colon.
Biomed. Res. 30, 149-156. doi: 10.2220/biomedres.30.149.

Thomas, E. A., Bertrand, P. P., and Bornstein, J. C. (2000). A computer simulation of recurrent, excitatory networks of sensory neurons of the gut in guinea-pig. Neurosci. Lett. 287, 137-140.

Tran, V. S., Marion-Audibert, A. M., Karatekin, E., Huet, S., Cribier, S., Guillaumie, K., Chapuis, C., Desnos, C., Darchen, F., and Henry, J. P. (2004). Serotonin secretion by human carcinoid BON cells. Ann. N. Y. Acad. Sci. 1014, 179-188.

Tsukamoto, K., Ariga, H., Mantyh, C., Pappas, T. N., Yanagi, H., Yamamura, T., and Takahashi, T. (2007). Luminally released serotonin stimulates colonic motility and accelerates colonic transit in rats. Am. J. Physiol. Regul. Integr. Comp. Physiol. 293, R64-R69.

Tuladhar, B. R., Kaisar, M., and Naylor, R. J. (1997). Evidence for a 5-HT3 receptor involvement in the facilitation of peristalsis on mucosal application of 5-HT in the guinea pig isolated ileum. Br. J. Pharmacol. 122, 1174-1178.

Vanden Berghe, P. (2008). Electrochemical detection of neurotransmitters in the gut wall. Neurogastroenterol. Motil.20, 1185-1188.
Wellendorph, P., Johansen, L. D., and Brauner-Osborne, H. (2009). Molecular pharmacology of promiscuous seven transmembrane receptors sensing organic nutrients. Mol. Pharmacol. 76, 453-465.

Whitehead, R. H., and Robinson, P. S. (2009). Establishment of conditionally immortalized epithelial cell lines from the intestinal tissue of adult normal and transgenic mice. Am. J. Physiol. Gastrointest. Liver Physiol. 296, G455-G460.

Yabuki, A., Ojima, T., Kojima, M., Nishi, Y., Mifune, H., Matsumoto, M. Kamimura, R., Masuyama, T., and Suzuki, S. (2004). Characterization and species differences in gastric ghrelin cells from mice, rats and hamsters. J. Anat. 205, 239-246.

Yadav, V. K., Ryu, J. H., Suda, N., Tanaka, K. F., Gingrich, J. A., Schutz, G., Glorieux, F. H., Chiang, C. Y., Zajac, J. D., Insogna, K. L., Mann, J. J., Hen, R. Ducy, P., and Karsenty, G. (2008). Lrp5 controls bone formation by inhibiting serotonin synthesis in the duodenum. Cell 135, 825-837.

Young, R. L., Sutherland, K., Pezos, N., Brierley, S. M., Horowitz, M. K., Rayner, C. K., and Blackshaw, L. A (2009). Expression of taste receptor molecules in the upper gastrointestinal tract in humans with and without type 2 diabetes. Gut 58, 337-346.

Zagorodnyuk, V. P., Brookes, S. J., and Spencer,N.J.(2009).Structure-function relationship of sensory endings in the gut and bladder. Auton. Neurosci. doi: 10.1016/j.autneu.2009.07.018.

Conflict of Interest Statement: The author declares that the research was conducted in the absence of any commercial or financial relationships that could be construed as a potential conflict of interest.

Received: 14 August 2009; paper pending published: 28 September 2009; accepted: 18 November 2009; published online: 04 December 2009.

Citation: Bertrand PP (2009) The cornucopia of intestinal chemosensory transduction. Front. Neurosci. 3:48. doi: 10.3389/neuro.21.003.2009

This article was submitted to Frontiers in Autonomic Neuroscience, a specialty of Frontiers in Neuroscience.

Copyright (c) 2009 Bertrand. This is an open-access article subject to a nonexclusive license between the authors and Frontiers Media SA, which permits use, distribution and reproduction in other forums, provided the original authors and source are credited and other Frontiers conditions are complied with. 